Article

\title{
How Do Mega Projects Alter the City to Be More Sustainable? Spatial Changes Following the Seoul Cheonggyecheon Restoration Project in South Korea
}

\author{
Chehyun Ryu ${ }^{1, *}$ and Youngsang Kwon ${ }^{2, *}$ \\ 1 Department of Civil and Environmental Engineering, Seoul National University, Gwanak-ro 1, Gwanak-gu, \\ Seoul 08826, Korea \\ 2 Department of Civil and Environmental Engineering, Integrated Research Institute of Construction and \\ Environmental Engineering, Seoul National University, Gwanak-ro 1, Gwanak-gu, Seoul 08826, Korea \\ * Correspondence: chr2704@hanmail.net (C.R.); yskwon@snu.ac.kr (Y.K.); Tel.: +82-2-880-8200 (Y.K.)
}

Academic Editor: Tan Yigitcanlar

Received: 27 September 2016; Accepted: 9 November 2016; Published: 16 November 2016

\begin{abstract}
Urban megaprojects change the city in various ways over a long period of time. These changes may be very clear and calculable, but it is the changes that follow which are unpredictable and extensive. Especially in fast-changing cities like Seoul, Korea, projects like the Cheonggyecheon Restoration have massive effects on the surrounding environment. The purpose of this study is to analyze the spatial changes in the downtown area after the Cheonggycheon Restoration Project (2005). The economic; social, and physical effect and the outcome of the restoration project have been studied before the restoration, but the actual changes that occurred afterwards were understudied. Since subsequent spatial changes in the surrounding area occur over a long period, continuous observation on the physical effects should be made. Thus, unlike most studies that focus on the immediate before and after effect of the Cheonggycheon Restoration Project, this study focuses on the ten years of physical changes that followed the restoration. The study covers roughly fourteen large blocks, which were divided into seven categories based on current land use and the historical background of the city form. Physical changes of newly-built buildings, the number of renovations or building extensions, and socio-spatial changes, such as the rise and fall of urban industries, changes in building use, and overall changes in the characteristic of the blocks, were analyzed in accordance with their historical development of the city form. Commemorating the 10th anniversary of the Cheonggyecheon Restoration project, this study provides a better understanding of the overall effect of the project.
\end{abstract}

Keywords: mega project; urban morphology; spatial changes; Cheonggyecheon; Seoul; urban regeneration

\section{Introduction}

It is a widely held belief that cities must change, or they will wither and die. One of the key problems of urbanization is how to cope with these changes while retaining the structures constructed and maintained by previous generations [1-3]. Too often do we find places with years of urban history disappear as a result of thoughtless development. Especially in Asian countries that experienced urbanization in a short period of time, modernization is often followed by demolition of existing urban structures. Seoul is no exception. After the Korean War (1953), the priority was to rebuild the city damaged by the war and to escape extreme poverty [4-6]. Constructing tall concrete buildings was a symbol of national development, and modernizing the country's capital (Seoul has 10 million residents, which is one-fifth of the national population [7]) was a priority. Preserving the traditional spatial structures established since 1394 became a priority only when the nation emerged from poverty and became stabilized in the 1990s. 
In the 1990s, concerns were raised among the City Planning Commission and professionals about the thoughtless developments destroying the city form. This was especially notable, since the Seoul CBD area (the capital of the Joseon Dynasty was limited to what is now the CBD area, and the current area of Seoul is $605 \mathrm{~km}^{2}$ ) has been the country's capital for over 600 years [8-10] and is filled with meaningful places that portray the lives of previous generations. In 2000, the first CBD plan was made to enhance global competitiveness by considering the different characteristics of the CBD area. In this context, the restoration of Cheonggyecheon (Cheonggycheon Project) was an excellent example of restoring the CBD area [9,11-13].

The Cheonggyecheon Restoration Project holds a very significant meaning in Seoul, Korea. It symbolizes a major paradigm shift in Seoul city planning from quantitative development to improving the amenity and livability of the city. The project attracted much national and international attention and has been attracting 20 million visitors and tourists annually [3,14-17].

\subsection{History of Cheonggyecheon}

One of the reasons why the Cheonggyecheon Project was highly spotlighted was because of its historical value. When King Taejo founded the Joseon Dynasty in 1392, he established Hanyang (the current Seoul CBD area) as the capital. In the middle of the new capital flowed Cheonggyecheon from west to east, dividing Hanyang into two (Figure 1). Since the stream was the main water source of the capital, many attempts to control its water level was made throughout the Joseon Dynasty. After the Korean War (1950-1953), a massive refugee camp was formed along Cheonggyecheon (Figure 2), and the sudden overpopulation caused the stream to turn into a sewer which began endangering public health. Subsequently, from 1955 to 1961, Cheonggyecheon was covered by building a road on top of it [18]. As Seoul became more modernized during the 1960s, the number of cars increased, and an elevated highway (Samil Elevated Bypass) was built on top of the existing road covering Cheonggyecheon in 1976. At the time, the elevated highway was the symbol of modernization, and many modern buildings were constructed along the highway.

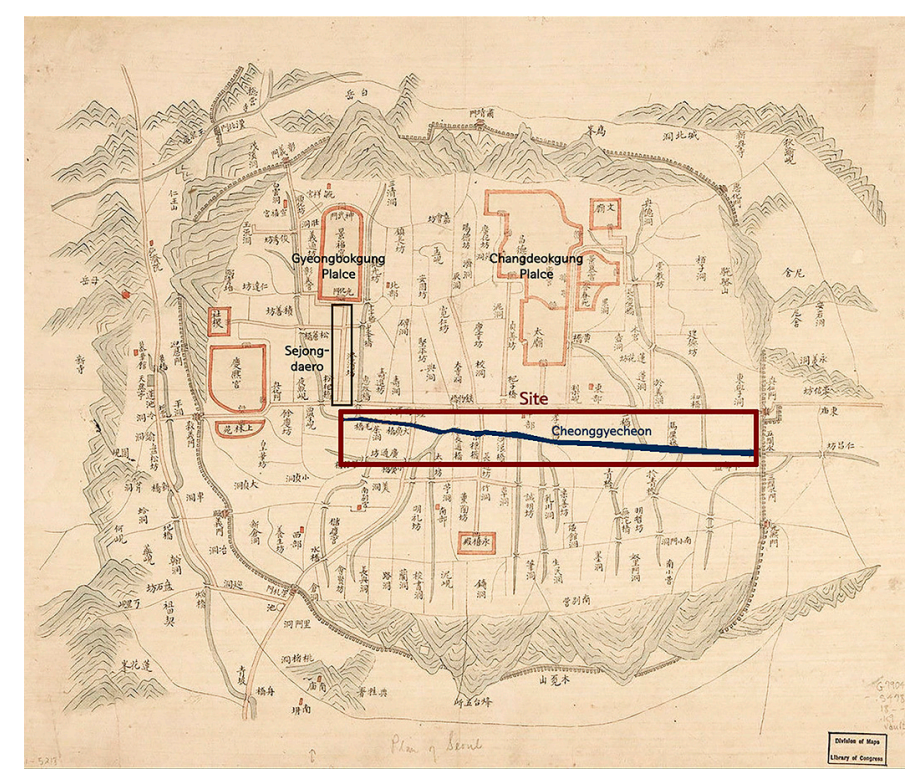

Figure 1. Old map of Hanyang (Library of Congress). 
In 1992, the Korean Society of Civil Engineering determined that the elevated highway was no longer safe to use, and the idea of restoring Cheonggyecheon was discussed among the academia and city planners $[10,19,20]$. Restoration of the ancient stream became a hot issue during the mayoral election of 2002 [21]. As the two main candidates took separate sides on the issue, the restoration project became a topic of national interest. While candidate Min-suk Kim opposed the idea, candidate Myung-bak Lee made the restoration project his top campaign priority [20]. Following the election of candidate Lee in 2002 (74.6\% of the respondents supported the restoration of Cheonggyecheon [21]), the Cheonggyecheon Restoration Project Headquarters was established.

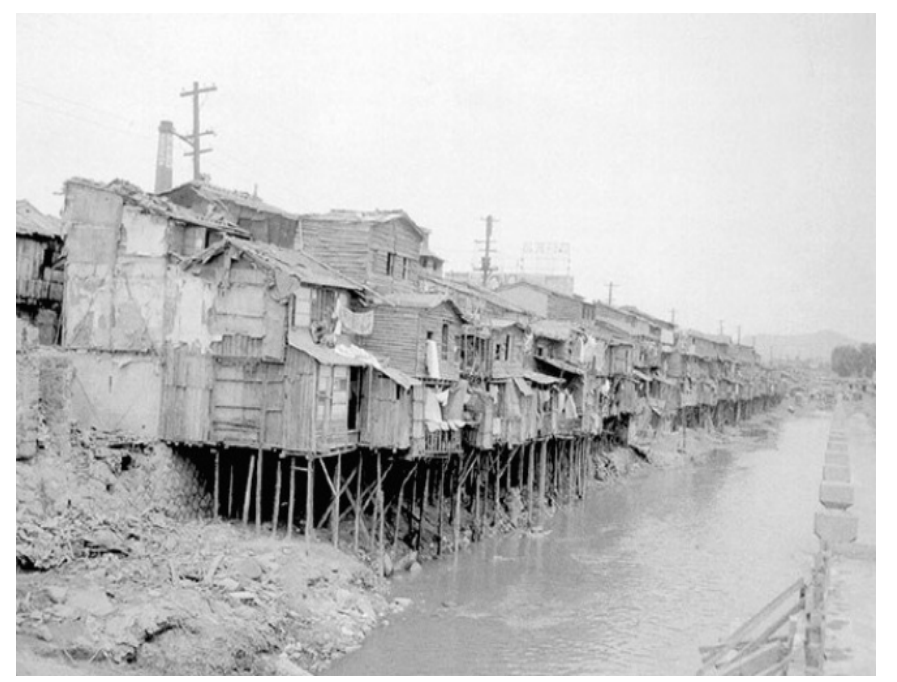

Figure 2. Refugee camp along Cheonggyecheon (Seoul City History).

\subsection{Process of Cheonggyecheon Restoration Project}

Cheonggyecheon was restored in 27 months, between 2003 and 2005, with a total cost of $\$ 400$ million (Discovery Channel [22]) under Lee's reign. The total length of the restoration project was $5.4 \mathrm{~km}$ and includes 22 bridges. It was divided into three segments, and each segment was bid to different consortiums of construction and engineering companies [20].

The top two important issues of the restoration process were the traffic and the relocation of Cheonggyecheon merchants. The elevated highway was notorious for its traffic congestion, with 168,000 cars passing through it daily [23]. One of the reasons for opposing the restoration project was that it will cause severe traffic problems in the city. However, due to improved bus services, longer subway operation time, new bus lines circling the $\mathrm{CBD}$ area, and raised parking rates, the project did not cause many traffic problems [20].

Being one of Korea's main industrial clusters from the 1960s, the Cheonggyecheon area was filled with many small industrial shops. There were 60,000 shops, with 220,000 merchants and over 3000 street vendors. Around 42,000 meetings with the merchants were held by the Seoul Metropolitan Government to agree on a settlement. One of the principles was no cash compensation, but several indirect financial supports, such as business loans, funding for facility improvements and scholarships were made [20] (a total of $\$ 70$ million was supported over 2331 offers). The merchants who agreed on relocating were to be settled in a mall that was to be constructed in the south area of Seoul. After 27 months of tight schedule, Cheonggyecheon was restored on 1 October 2005 (Figure 3). 

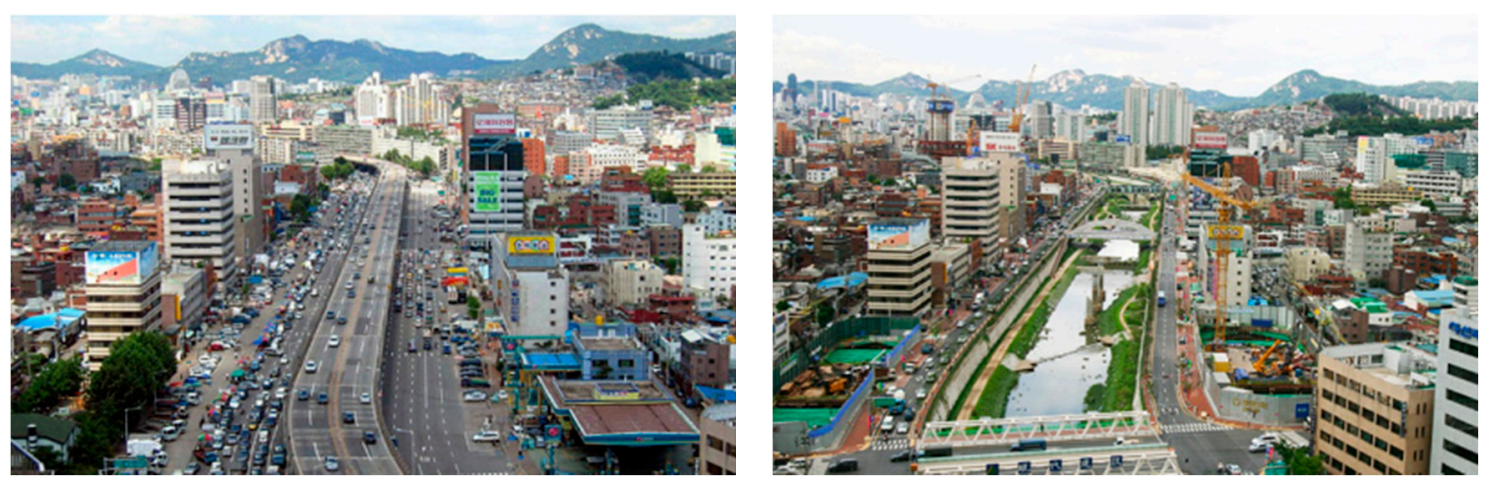

Figure 3. Before and ater Cheonggytecheon Development (http:/ / egloos.com [24]).

\section{Methods}

As the Cheonggycheon Restoration Project reached its 10th anniversary this year, many aspects of the project were reviewed in articles to evaluate its long-term results. The CGC project has contributed to urban greenery, a reduction of the city's heat island effect, tourism and revitalization of the CBD area [25]. However, the relocation of Cheonggyecheon merchants to Garden Five Mall turned out to be a failure, as the cost for moving into the mall became much higher than what the government had first offered and the mall turned out to be unsuccessful [26]. There has also been numerous studies on the effects of the CGC project on waterfront usage [27,28], environmental change [29,30], and tourism over the last decade. Several studies regarding the effects of the Cheonggyecheon Project on the city form $[14,23]$ were made by government institutions for a before-and-after comparison. However, most of them were conducted while Cheonggyecheon was under construction (2003-2005), so long-term changes were not studied. A decade may be a short time for discussing spatial changes, but regarding the strong impact of the CGC project and the unprecedented pace at which non-Western countries are changing [31], ten years may be sufficient to identify the changes or the directionality of the changes in the city form.

It is very crucial to study the spatial changes of the surrounding area after a megaproject like the Cheonggyecheon Restoration, because sudden changes in the environment cause increased land price and visitors, which leads to redevelopment or alterations of existing buildings. Such changes are natural, but some changes must be controlled to prevent the city forms that had been built over centuries from becoming lost in a few years, and this is especially the case in a fast-changing city like Seoul. Thus, this research aims to analyze the spatial changes that occurred after the Cheonggyecheon Restoration Project.

The site is about three kilometers in length, spanning from the starting point of Cheonggyecheon to Dongdaemun Station, and consists of twelve adjacent blocks (Figure 4). The reason for choosing this specific site was because of its historical value from the perspective of city form and its unique composition. Various spatial forms exist in this site, each very adequate for its land use and historical background. The distinction between them are very clear and visible. The starting point of the stream is the core of the CBD, which is characterized by large skyscrapers and office buildings. Towards the downstream are $4-5$ story commercial buildings, mostly restaurants and coffee shops, followed by a block of 1-2 story small industrial shops. Further along the stream are traditional markets and the Dongdaemun fashion complex. At least five distinctive spatial features exist in this twelve block radius, which makes this area more diverse and special.

The blocks were categorized into seven groups by theirits land use and form (Figure 4), and the spatial changes were analyzed based on historical background and status of each group. Digital cadastral maps of 2004, 2010, and 2015 obtained from a government website (http://www.nsic.go.kr/ndsi/main. do [32]) were used for comparison, along with GIS mapping tools. Yearly changes in structures, such as road structure, newly-built buildings, renovated buildings, building usage change, and building 
coverage were analyzed from 2003-2015 using building permit data (http://www.eais.go.kr/ [33]). The yearly changes of the Cheonggyecheon area were manually obtained by matching the area code with the building permit data which contains information on every construction work that had been permitted in the area. Other characteristics in the spatial structure were studied in accordance with the historical transformation of the place. The basic methodology, used in studies by Conzen and Caiggia, is a more traditional method of analyzing urban forms. There have been many attempts in morphological areas to simplify the concepts and methods to obtain a wider appreciation of urban morphological theories [34], which led to the use of space syntax or other spatial analysis tools using GIS [34-36]. These "simplified and modern" methods have their advantages in analyzing some aspects of the urban form, but since the purpose of this study is to examine spatial changes in accordance with existing characteristics, a more traditional and descriptive analysis seemed adequate.

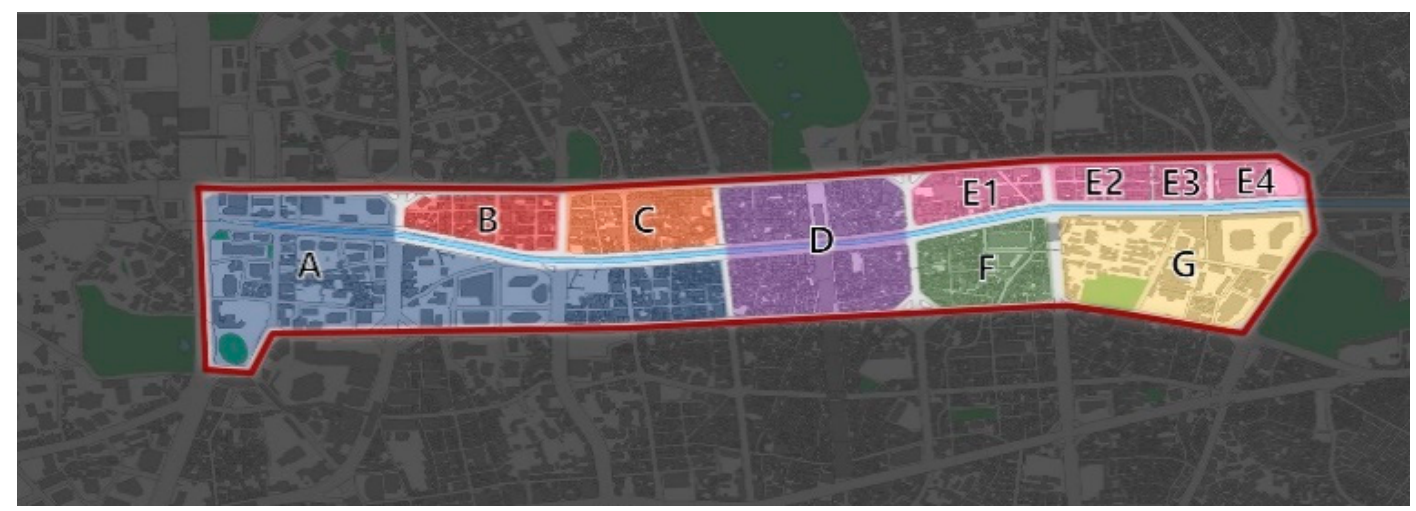

Figure 4. Research site (The changes in Area D are not considered due to redevelopment plans).

Structural changes in the Cheonggyecheon area vary depending on regional characteristics, but the overall changes are evident, even visible by comparing digital cadastral maps (Figure 5). A total of 49 buildings were newly built, and 140 heavy renovations were made during the last 10 years (2006-2015). Most small buildings were redeveloped into large skyscrapers which, in turn, led to small lots to combine into a single lot.

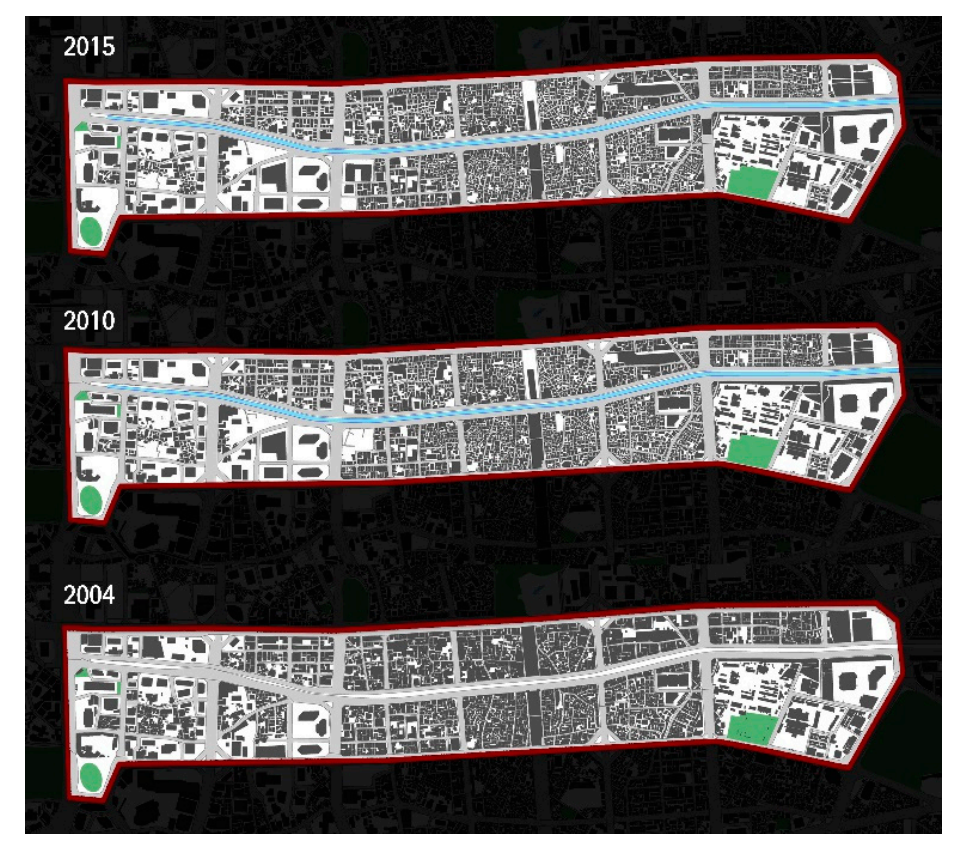

Figure 5. Digital cadastral maps of 2004, 2010, and 2015. 
For further analysis, the site was divided into seven areas according to current land use and site history. The categorization is based on "Seoul CBD Development Plans regarding Cheonggyecheon Restoration Project" [23] (Figure 4). Area A is a modern business district while Area B is a commercial district. Traditional industrial complexes are located in Areas C, D, and F. Areas C and F are left to be rehabilitated autonomously, while Area D is to be redeveloped. Areas E and G are traditional marketplaces that are now mixed with modern commercial buildings [7,25].

\section{Results}

\subsection{Modernized Business District and Commercial Area}

Most of the modern office buildings are located along Sejong-daero (Figure 1), an $80 \mathrm{~m}$ boulevard stretching southward from Gyeongbokgung Palace, which is the main core in the CBD area (Area A in Figure 4). Sejong-daero has been the symbol of Seoul for 600 years and, since then, most of the important buildings were located along the road (Figure 1). After Cheonggyecheon Stream was restored, the blocks most adjacent to the Sejong-daero were redeveloped. The adjacent blocks were categorized as the downtown core area of Seoul CBD and redevelopment plans were encouraged to demolish existing small buildings (Figure 6).

In 2004, small buildings coexisted with large office buildings in the downtown core area (Figure 4, Area A), but by 2015, most of the small structures were redeveloped into skyscrapers. The small structures that were torn down were mostly small housings or commercial buildings. Along with the redevelopment, most of the small roads were removed and pedestrian roads were widened (pedestrian roads are broadened due to the setback of office buildings).

Area B (Gwanchuldong) consists mostly of modern-day restaurants and coffee shops, alongside academic institutions, such as foreign language institutes. The building spread is relatively uniform with an average building coverage of $82.6 \%$. There are 14 blocks and 170 buildings in this area, of which most are under five stories high with an average FAR of $345.5 \%$. Over $85 \%$ of the lots are smaller than $300 \mathrm{~m}^{2}$, and larger buildings are divided into a few different shops, with each smaller than $200 \mathrm{~m}^{2}$. Over $85 \%$ of the buildings were built before 1990 , but most of them have been well maintained, so the street level is fairly uniform and well managed; small commercial shops are aligned along the 5-7 m streets in a grid.

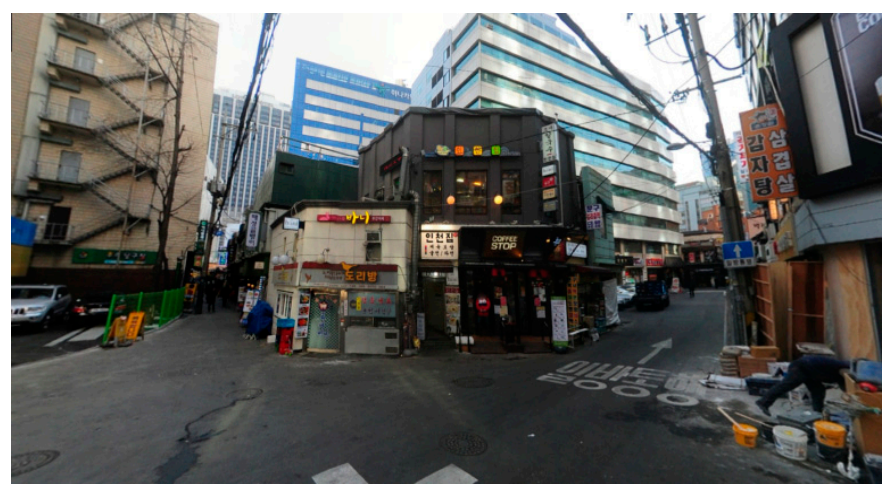

Figure 6. Exisiting small buildings in the downtown core area (Daum Street View [37]).

The urban structure of the Gwanchuldong area is well conserved compared to the downtown core (A) area. The structure of this area is very unique, because a number of naturally-developed structures erected before the 1920s still exist within the area, creating what is similar to a chronicle of urban changes. In 1952, the Land Compartmentalization and Rearrangement Project was carried out to recover the damages after the Korean War (1950). Gwanchuldong was one of the areas renewed by the post-war recovery project, and the structures made then still remain. At the time, parts of the Gwanchuldong area not damaged by the war were excluded from the recovery plan, leaving 
small naturally-built structures within the newly established grid (Figure 7). The historical meaning of this area was approved by the government and district plans were made in 2005 to maintain its urban structures.
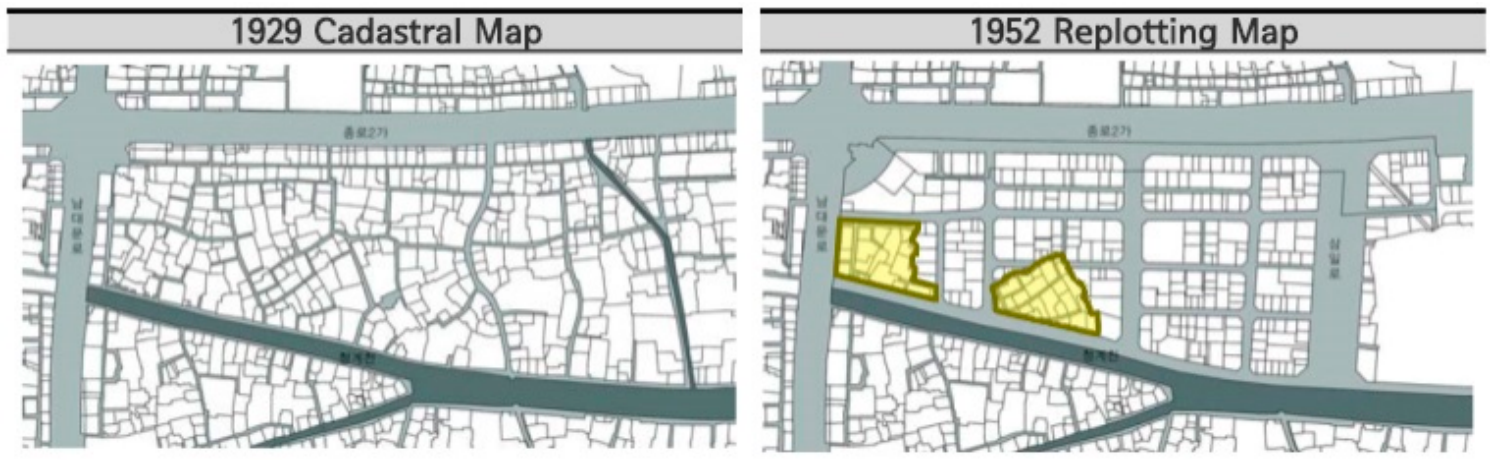

Figure 7. Before and After Land Compartmentalization Project (Song et al., 2006 [38]).

After the CGC project, many buildings were extended or heavily repaired (Table 1, Figure 8). Especially in the case of the buildings facing Cheonggyecheon stream, 15 out of 30 shops had changed façades between 2003 and 2006 [18,28]. When the elevated highway existed, the façades facing the highway were meaningless, but after the restoration, the streets became pedestrian-friendly. For example, the number of commercial shops, such as cafés or restaurants, increased and terraces were built along the street (Figure 9).

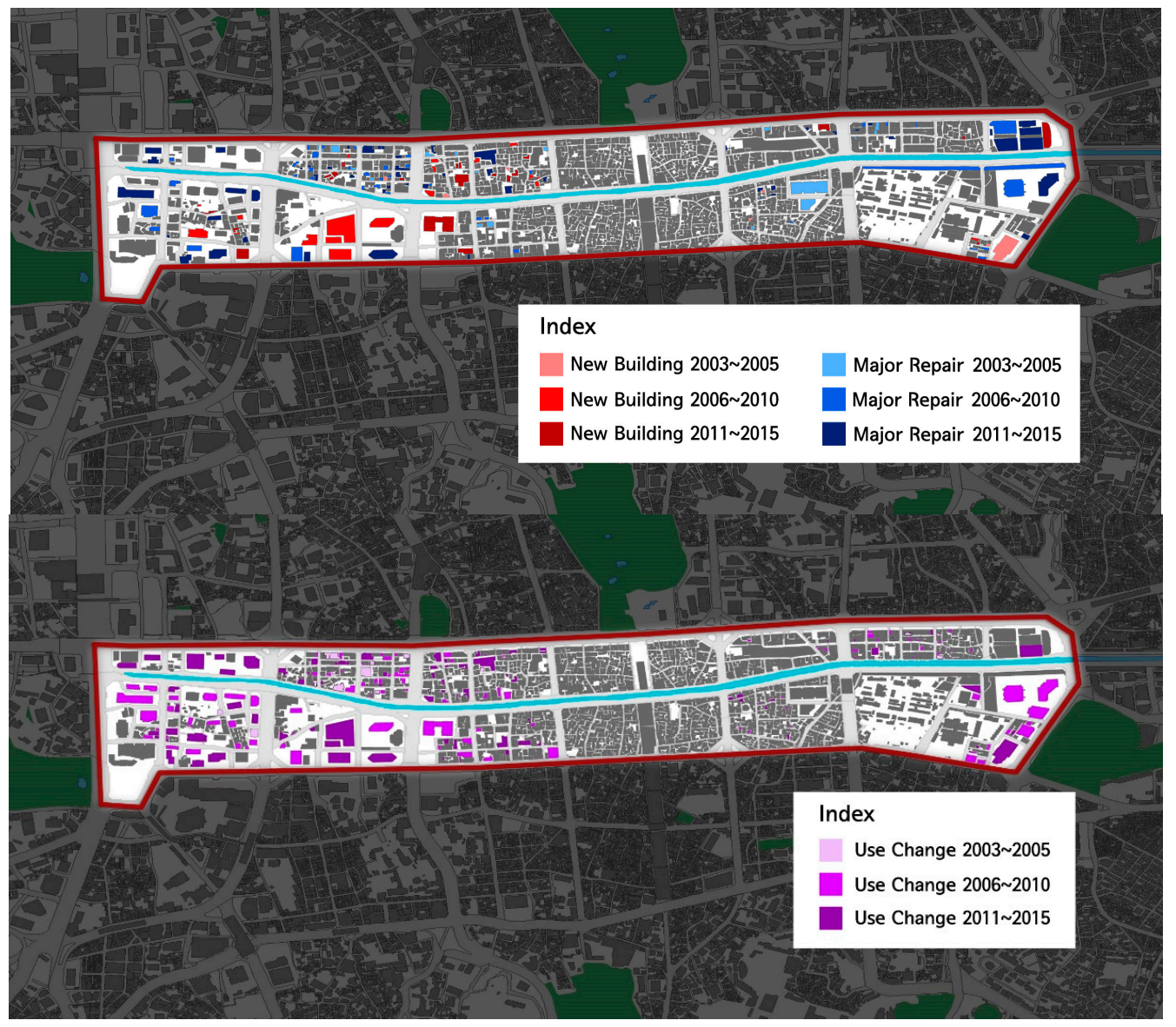

Figure 8. Changes in the Cheonggyecheon area from 2003-2015 (Source: Author based on government statistics [33]). 

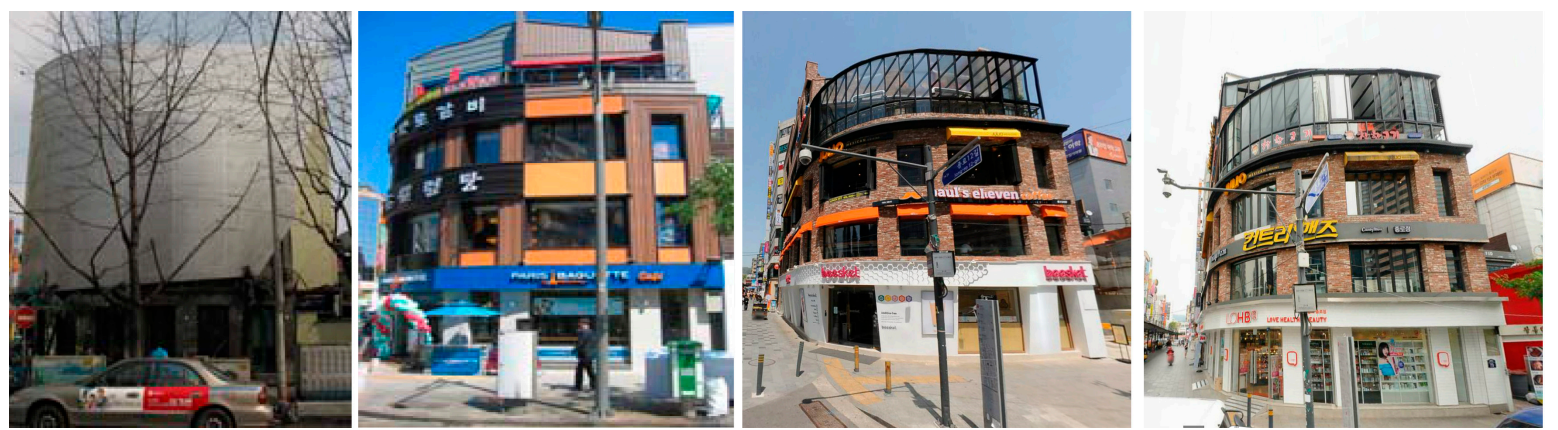

Figure 9. Changes in building use and façade after the CGC Project (From left: 2003, 2006 (Song et al., 2006 [38]), 2012, 2016 (Daum Street View [37]).

Table 1. Number of changes in the Cheonggyecheon area.

\begin{tabular}{cccc}
\hline Year & New Buildings & Major Repairs & Use Change \\
\hline $2003-2005$ & 7 & 22 & 13 \\
$2006-2010$ & 23 & 67 & 124 \\
$2011-2015$ & 26 & 83 & 164 \\
Total & 56 & 172 & 301 \\
\hline
\end{tabular}

In the past five years, six new buildings were built in Area B (Table 2), which is a large number, since only 26 buildings were built in the site between 2011 and 2015. Since this site is the main commercial area in Cheonggyecheon, the vitality of the place has increased after the restoration project. Thus, renovations and building extensions have continued following the restoration.

Table 2. Number of changes in Area B.

\begin{tabular}{cccc}
\hline Year & New Buildings & Major Repairs & Use Change \\
\hline $2003-2005$ & 1 & 6 & 15 \\
$2006-2010$ & 1 & 25 & 25 \\
$2011-2015$ & 6 & 18 & 28 \\
Total & 8 & 49 & 68 \\
\hline
\end{tabular}

\subsection{Distorting Traditional Industrial Complex}

Area C (Gwansudong) still maintains the same structural pattern since the Joseon dynasty [39]. Along with Areas $\mathrm{E}$ and $\mathrm{F}$, small manufacturing shops are concentrated in these areas forming a cluster of textile, metal, electric, and printing industries. These clusters were formed through 1960-1970 and had been the driving force of Korean industrial development. The industries were concentrated along the Cheonggyecheon elevated highway and had been the symbol of urban industry until Cheonggyecheon stream was restored.

The merchants of Cheonggyecheon are mostly middle-class people owning small individual shops. They are mostly wholesalers supplying their commodities to larger corporations or organizations. Out of a total of 60,000 Cheonggyecheon merchants, $10 \%$ of them were relocated. (One thousand forty-five merchants were relocated to Garden Five Mall in the far east of Seoul, which opened in 2010. However, due to economic reasons and lack of customers, only 100 merchants remain in the mall. The rest of the shops remained but due to increase of land price and redevelopment plans, many industrial shops are being replaced by high office buildings or commercial shops. Land prices in the Gwansudong area increased 50\%-200\% since the CGC Project (Seoul land information system) while the average land price increase in Seoul from 2004 to 2014 was $2.5 \%$. 
Since the urban structures of Gwansudong (C) was untouched, most roads remain very narrow and irregular. According to a research conducted by the Seoul Development Institute in 2000, out of a total length of $1379 \mathrm{~m}$ of roads, only $8 \%$ was wider than $4 \mathrm{~m}$. During the early 2000s part of the road was broadened to make entrance for firetrucks (Analysis of Urban Form Transformation for a Decade of Old Block in the Downtown of Seoul, Korea).

City plans for the Seoul CBD area was first made in 2000. Until then, the urban redevelopment plan was the only plan in the CBD area which encouraged demolition of old buildings, replacing them with modern skyscrapers. In the process many historical places vanished, arousing the concern of many city planners. In 2000, first CBD plan was issued to avoid redevelopment based on demolition and to protect the characteristics of the CBD area. In January 2000, the Seoul Downtown Basic Management Plan was published by the Seoul Development Institute. Later it was revised as the "Seoul Downtown Development Plan" to further manage the changes made by the Cheonggyecheon Restoration Project.

Gwansudong was categorized as an autonomous rehabilitation area in 2004. It is an area where regulations on buildings and parking lots are mitigated to enhance individual building renovations which will hopefully result in regional rehabilitation. Public involvement is minimized to constructing fire roads and infrastructure. The purpose is to maintain the urban structure while still enhancing the physical environment, but the results are rather doubtful.

From 2011-2015, a total of seven new buildings were constructed (Table 3) of which all of them are hotels or motels, while five newly-built buildings from 2006 to 2010 are small livelihood facilities, such as manufacturing stores or offices. Recently, most of the buildings that were newly built or renovated in this area are accommodations business. After the CGC project, Cheonggyecheon became a major tourist site and since this area has less regulation compared to other areas near Cheonggyecheon, the growing demand for accommodation is showing up in the Gwansudong area. While the competitiveness of the existing industry is declining, demand for the accommodation industry is increasing, replacing the old industry with new ones. As the society develops new demands, changes in urban industry is a very natural phenomenon, but building new motels without any regulations or planning in a traditional urban fabric harms the unity and characteristic of the urban structure. Additionally, the narrow maze-like roads and aged buildings make the block very vulnerable to fire, which is a dangerous condition for the lodging industry.

Table 3. Number of changes in Area C.

\begin{tabular}{cccc}
\hline Year & New Buildings & Major Repairs & Use Change \\
\hline $2003-2005$ & 3 & 3 & 1 \\
$2006-2010$ & 5 & 4 & 14 \\
$2011-2015$ & 7 & 5 & 15 \\
Total & 15 & 12 & 30 \\
\hline
\end{tabular}

\subsection{Symbol of Modernism and Its Faith}

The traditional industry complex extends to area D (Figure 4). The large rectangular building embedded in the middle of this area is Sewoon Sanga Commercial Complex. Sewoon Sanga was built in 1967 by a famous architecture Kim, Sugeun. Along with the Cheonggyecheon overbridge, its massive concrete structure symbolized the modern development of Seoul (Yoo, 1994). It was built as the largest electronics market in Asia, but with Gangnam development and Yongsan Electronics Market, Sewoon Sanga deteriorated leaving many vacant stores [40]. The complex, a massive residential and commercial complex. Although it had once been the symbol of Korean modern architecture, it was to be redeveloped in 2004 due to old age. A public competition took place, and blueprints were made (the existing structures were to be demolished and new high-rise buildings office buildings and hotels were to take its place) (Figure 10), but the redevelopment plan was called off to preserve the historic meaning of the structure. Since the redevelopment plan was cancelled in 2013, new plans are to be made regarding the remodeling of Sewoon Sanga. Detailed planning is not yet in progress, so the site 
is currently on hold. The electric and metal industry located in this area is still vital, but since the site is awaiting another plan, not much renovation or changes have been made.

The Cheonggyecheon area has been a major urban industrial complex for electric, textile, metal, and printing industries. The printing industry developed during the Japanese Colonial era (1910-1945), expanded up to 6000 individual businesses during the post-war period (late 1960s-1970), and are located in parts of Areas A, C, and F. While the printing industry in Area A focused on posters and commercial printing, the businesses in Area $C$ focused on trophies, medals, and materials related to government institutions. The printing businesses in Area F were mostly related to boxes, envelopes, and commercial printing for the U.S. Army and Dongdaemun market. For instance, the label tags for clothes made in Dongdaemun market were made in these printing shops [41]. Along with the printing and packing industry, the industry for subsidiary materials for clothes also settled in this area. In 1976, Bangsan market was built, and it is currently a special market for printing and packing. Bangsan market was built on the ground of Bangsan Elementary School, which was closed in September, 1976. The site is $9737 \mathrm{~m}^{2}$ and the total floor area of the market is $23,335 \mathrm{~m}^{2}$. The market consists of two three-story buildings with a basement floor. It was famous for various food supplies that came from the U.S. troops, but from the late 1980s, it became a special market for printing and packing when the wholesale services for processed food declined.

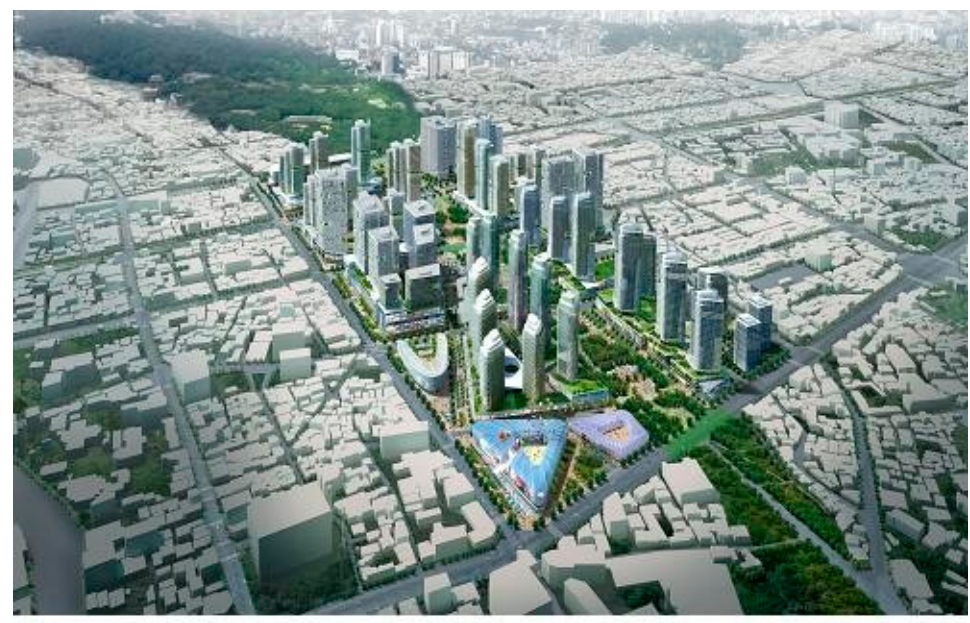

Figure 10. Blueprint of the Sewoon Sanga redevelopment plan (Naver news [42]).

Similar to Gwangjang market, Bangsan market is one of the few remaining wholesale commercial and industrial areas in downtown Seoul. The environment of this area is quite poor and unsafe, since it includes old buildings, difficult vehicle access, and narrow roads. Furthermore, both increased land price in the downtown area and the automation of the printing process have put these businesses under much pressure. Not many changes were made in the area following the Cheonggyecheon Restoration project; no new buildings were constructed and a relatively low number of renovations were made. With redevelopment plans in both the west block (Sewoon Sanga) and the east block (relocation of U.S. Army Corps of Engineers and the National Medical Center), not much investment was made in Area F. However, there is a strong possibility of the area changing once the adjacent areas are redeveloped $[40,43]$.

\subsection{Traditional Market and Modern Commercial Buildings}

While electric, textile, and metal industries are located in Areas C and D, printing, textile, and fashion industries are located in Areas E and F, between Sewoon Sanga blocks and Dongdaemun (Figure 4). Area $\mathrm{E}$ is unique, because it is characterized by uniform content, but varying structures. Most of the shops in Area E are fashion-related and date back to over a century ago [15,44,45], when merchants first established Gwangjang Corporation (Gwangjang Corporation still remains in 
Area E1 as a traditional market) in 1905. Since the Josun Dynasty, Dongdaemun market has been one of the top two traditional markets in Seoul [10]. The modern day Dongdaemun market was established following the Korean War in 1953, when refugees made a living by making clothes (more than $60 \%$ of the merchants in Dongdaemun market were refugees from the north who started out as street vendors). Since then, the market expanded until it became the largest clothing market in Seoul in the 1970s [46].

The modern buildings still standing in the Dongdaemun area were built in the 1970s, when the government issued a "modernization plan" for traditional markets. The plan was to clear small-scale markets and build large modern commercial buildings in their place (many traditional markets were replaced with modern buildings in the 1960s, including Namdaemun market, which is one of the two major traditional markets in Seoul [10]). However, the redevelopment of Dongdaemun market was different. It was redeveloped gradually-step by step, small areas at a time-which was very unusual at the time (Dongdaemun market was too broadly scattered and the independency of each cluster was too strong to be redeveloped into a few buildings [44]). Starting with Pyunghwa market (Pyunghwa market is a three-story concrete building over $200 \mathrm{~m}$ long, is the symbol of Dongdaemun market, and contains 2070 individual shops [46]) in 1962, the construction of new market buildings continued until the 1990s. The four large buildings in E4 (Figure 4) forms the Dongdaemun Shopping Complex, which was constructed in 1969. It has been remodeled and extended since then and currently contains 4300 shops with between 150,000 and 200,000 visitors a day [26].

The current urban structure in Areas E and G is a visual map of the history of Dongdaemun development. While E3 still maintains the same urban fabric of Dongdaemun market as when it was first developed in 1905, E2 and E3 display the urban structure created after the war, since it was rebuilt in the 1950s. E1 represents the traditional market (Gwangjang market) built in 1905, and the whole block operates as part of the market (Figure 11). Gwangjang market has gone through many renovations since the 1960s, and a more urban renewal project was carried out in 2003 to improve the environment of the market place.

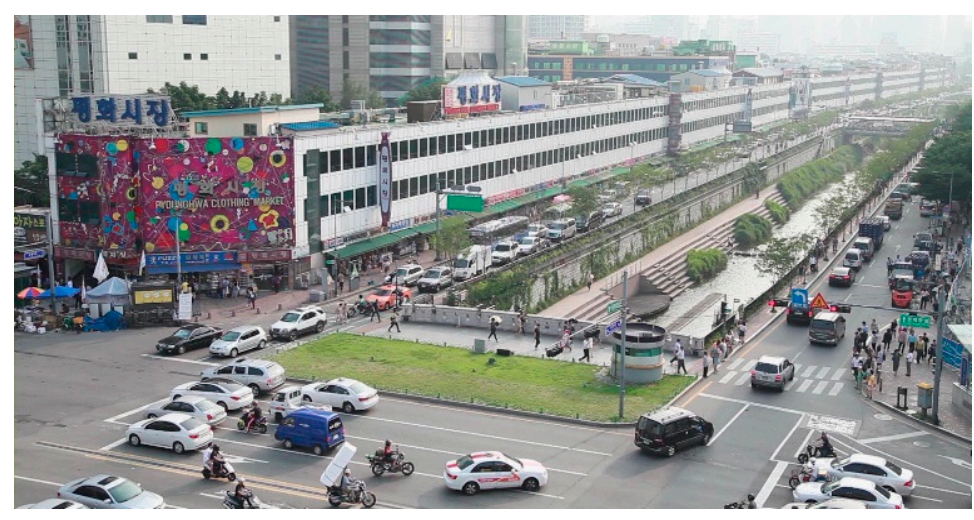

Figure 11. PyungHwa market and Cheonggycheon (Source: TBS [47]).

The urban structural changes in this area have been relatively small and gradual and were mostly limited to building repairs or use changes. Among the 22 renovations made in Area E, 12 were made during 2011-2015, while five renovations, each, were made in periods of 2006-2011 and 2003-2005 (Figure 9). One of the reasons for such gradual change was the Dongdaemun Merchant Association. The association has much influence over the entire market, so it prevents inharmonious construction and keeps the integrity of the place. Compared to Area C, where larger buildings were constructed throughout the block in a disorderly manner that degrades the uniformity of both structure and usage, Area E was developed with consistency. 
While Area E and Pyunghwa market are focused on wholesale [48,49], Area G is more trendy and retail-based. Following its construction in the 1990s (trendy shopping malls such as Miliore (1998) and Doota (1999) were developed, attracting many young visitors [45]), the modern shopping mall became a 24-h fashion complex with over 2.5 million foreign tourists visiting annually (Dongdaemun Special Tourist Zone). In 2002, it was appointed as Dongdaemun Special Tourist Zone, and more shopping malls, such as Good Morning City (2008) and Hello APM (2002), were constructed alongside DDP (Dongdaemun stadium, which was built in 1926 by the Japanese during the Japanese colonial era, was demolished and was replaced by Dongdaemun Design Plaza in 2013 (Figure 12). DDP is a state-of-the art design complex and park that supports a convention center, galleries, and a commercial area designed by Zaha Hadid [20]) (Dongdaemun Design Plaza) [50-52]. Compared to other blocks, Area $G$ underwent many usage changes, mostly from large commercial buildings. The newly-built buildings include a modern fashion mall (2008) and two accommodation businesses.

Further developments are to be made since the National Medical Center (2018) and the site of the U.S. Army Corps of Engineers are to be relocated (Figure 13). The site is appointed as a Special Planning District to develop the site $\left(669,072 \mathrm{~m}^{2}\right)$ into a special district for fashion, culture, and city tourism (Figure 14).

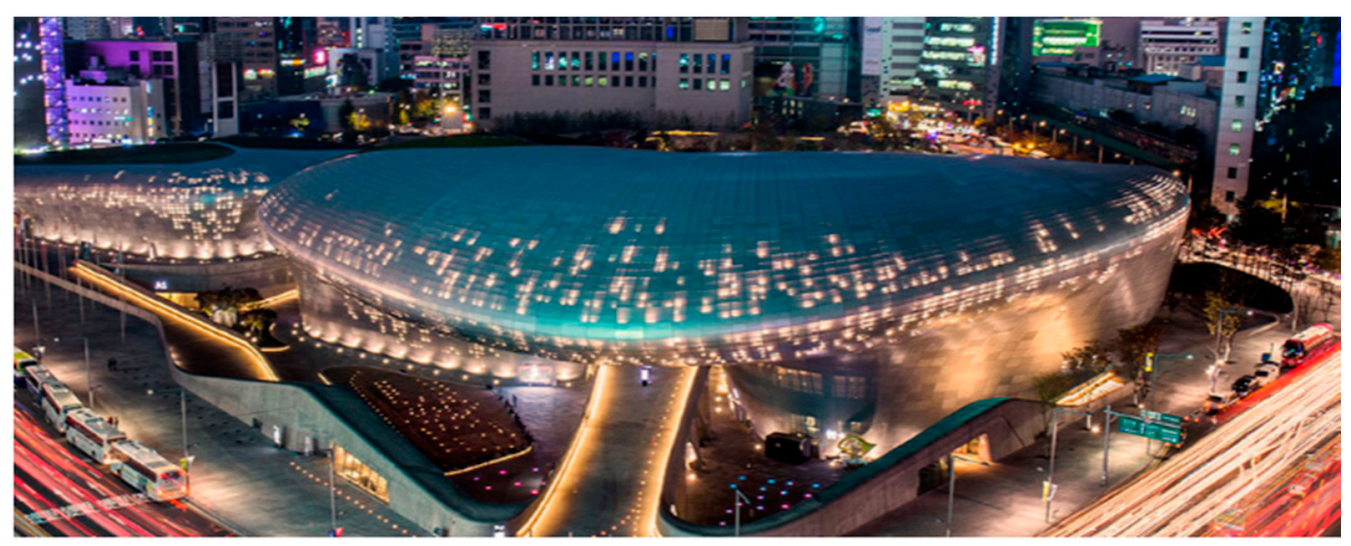

Figure 12. Dongdaemun Design Plaza (Design. Zaha Hadid, Source: www.ddp.or.kr [52]).

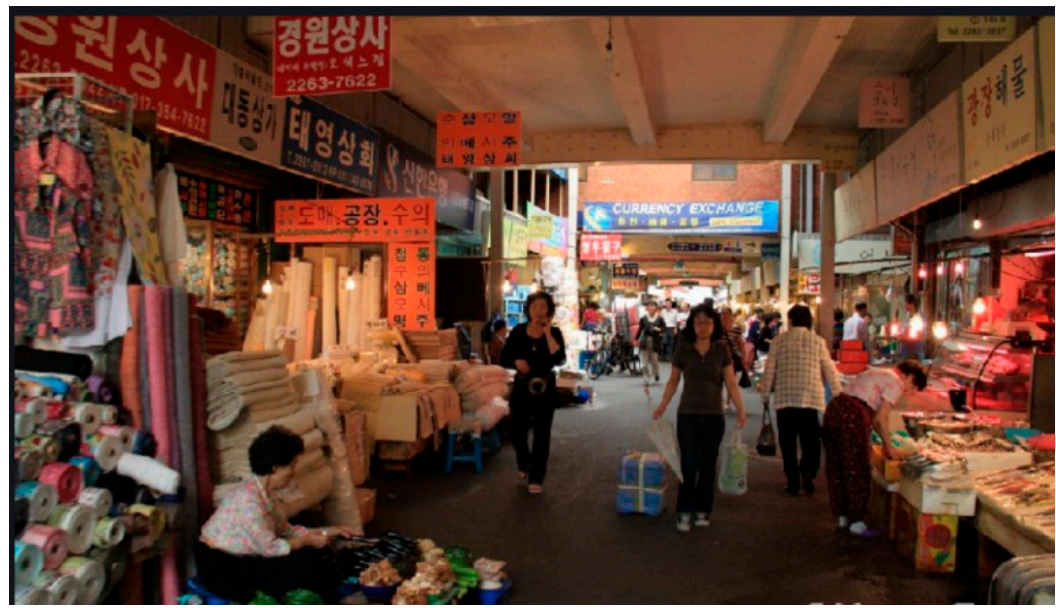

Figure 13. Gwangjang market (Source: Doopedia [53]). 


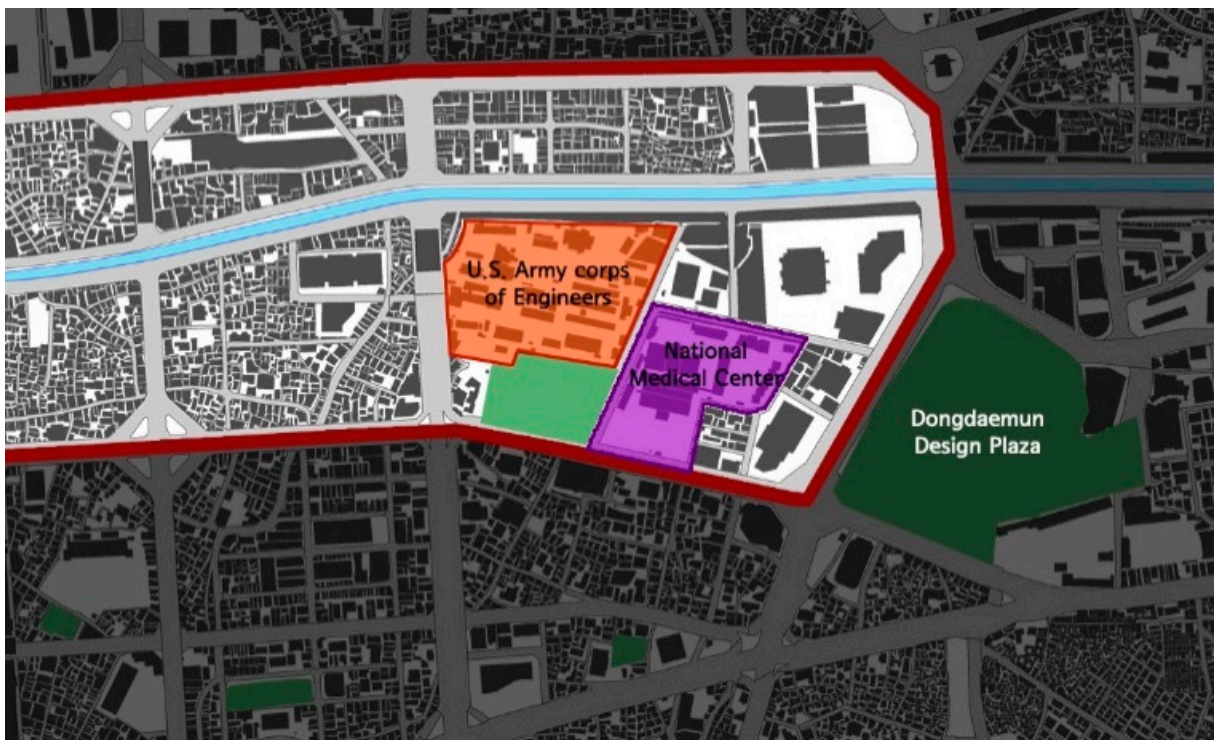

Figure 14. U.S Army corps and National Medical Center.

\section{Results and Discussion}

City-scale developments, such as Highline Park, Promenade de Paris, and the Cheonggycheon Restoration project, affect the entire city, with especially strong and long-lasting effects on the surrounding area. This study introduces the spatial changes that took place in downtown Seoul after the Cheonggycheon Restoration Project through space and time series analysis.

There have been many physical changes in the downtown area since Cheonggyecheon was restored. The changes differ based on pre-existing land use and urban structure. Overall, spatial changes were mostly increases in building size, combinations of lots, and broader pedestrian roads. In the case of building usage, service industries, such as restaurants, coffee shops, and the accommodation industry, generally increased, while traditional industrial shops decreased.

The most visible changes are shown in the business district (area A). There were some redevelopment projects in this area before Cheonggyecheon was restored, but the redevelopment process was accelerated after the CGC project. The redevelopment replaced small printing industries and offices with skyscrapers for financial companies or global corporates and continued to influence adjacent areas. Once Sewoon Sanga (area D) is redeveloped, there is a high possibility that the rest of area A-2 will be demolished and redeveloped.

The area that is the most vulnerable to change is the traditional industrial complex (area C). Many small size buildings were torn down to build medium-sized hotels or motels in this area. However, since there was no specific plan made for this area, the new buildings were constructed in a disorderly manner, and the mixture of small industrial shops and modern buildings created a rather unpleasant scenery. The city form in this area is of important historical significance, but narrow roads unfit for vehicle access has made it difficult to maintain its traditional form. In order to avoid this problem during rehabilitation, a new approach, rather than deregulation, seems necessary.

The Dongdaemun area is an exemplary case of positive interaction between the traditional market and modern commerce. The combination of the traditional Dongdaemun market founded in 1905, Pyunghwa market founded in 1962, and modern day fashion malls built in the 2000s, have created a fashion cluster that now attracts millions of visitors. Key factors contributing to its success are the flexibility of its operating system and gradual changes that followed in association with a tight network among the merchants [54]. Instead of first changing its built form, like many other traditional markets, the physical changes were gradual and adaptive. Following the restoration of Cheonggyecheon, the historical part of Dongdaemun (area E) was left unchanged, while a few new buildings were 
constructed in the modernized area (area G). Many buildings, including Pyunghwa market, which is the symbol of modernized Dongdaemun, underwent renovation, but radical changes were not made.

Overall, changes which took place in downtown Seoul in the last decade can be acknowledged through this study. Influential urban projects should be followed by continuous monitoring of surrounding areas, since the projects create and accelerate development in adjacent areas. In developing countries, the influence of certain government projects can be especially critical. For example, in the case of projects with political agendas, once the political purpose is served, follow up studies or management tends to decrease rapidly. Therefore, the kind of changes that downtown Seoul experienced can be referenced in other countries going through similar development.

\section{Conclusions}

The Cheonggyecheon Restoration Project has changed the overall image of downtown Seoul. While the elevated highway covering the stream had been a symbol of industrial development and modernization, the restoration of the stream has become a sign of a paradigm shift in urban development. The excessive budget put into this project proves that Seoul is now moving on to a more advanced stage of urban development, and the positive feedback from the general public implies that they support the new paradigm.

With the Cheonggycheon project as an example, Seoul's urban policy is shifting towards conserving historical heritage and increasing amenities for children. The return of the ancient stream has brought back a piece of the forgotten city and a place for people to enjoy nature in the middle of downtown. Since the restoration project in 2005, the ecological environment of Cheonggyecheon Stream is improving. Now, it is a home to over 300 different forms of plant life, and numerous animals and insects, providing a piece of nature in the busiest part of downtown Seoul. About 20 million people visit Cheonngycheon each year to enjoy the stream (Seoul Metropolitan Facilities Management Corporation, Seoul, Korea [55]). The high level of national and international support the CGC project received influenced other redevelopment plans. For example, the redevelopment plan to demolish Sewoon Commercial Complex, a prominent modern architecture, was overturned in order to conserve the building, and countless streams once covered by concrete were restored nationwide to provide habitat for various plant life and to provide additional amenities to the city.

The removal of the $5.9 \mathrm{~km}$ massive overpass has improved the vertical accessibility of downtown Seoul both visually and physically. With the disappearance of the story-high concrete mass, the visual corridor of the city opened, and the 22 bridges on Cheonggyecheon Stream linked the north and south sides of the downtown area. Actual plans to increase vertical accessibility are being carried out by naming vertical roads, increasing street level activities, and enhancing pedestrian access. It has been a decade since the Cheonggyecheon Restoration Project, and it has influenced the city in various ways. The influence cannot be quantified, but it is crucial to continue monitoring and analyzing the changes in order to improve the quality of the city.

While the focus of this study is on describing the changes, a tighter analysis can be developed in a further study by developing a multi-criteria framework to evaluate the various aspects of the changes due to the Cheonggyecheon Restoration Project. Such analysis will be viable to not only this project, but also to future government development policies [56].

Acknowledgments: This research was supported by a grant [MPSS-NH-2015-79] through the Disaster and Safety Management Institute funded by Ministry of Public Safety and Security of Korean government. This work (Grants No. C0353956) was supported by Business for Cooperative R\&D between Industry, Academy, and Research Institute funded Korea Small and Medium Business Administration in 2015. This research was supported by Basic Science Research Program through the National Research Foundation of Korea (NRF) funded by the Ministry of Education (2016R1D1A1A02937316). This work was supported by Creative-Pioneering Researchers Program through Seoul National University (SNU). 
Author Contributions: Chehyun Ryu committed to the data collection, analysis and writing the manuscript. Youngsang Kwon completed the writing work of manuscript and corresponding parts. Both authors have read and approved the final manuscript.

Conflicts of Interest: The authors declare no conflict of interest.

\section{References}

1. Bae, H. Urban Stream restoration in Korea: Design considerations and residents' willingness to pay. Urban For. Urban Green. 2011, 10, 119-126. [CrossRef]

2. Larkham, P.J. Conservation and the City; Routledge: Abingdon-on-Thames, UK, 2002.

3. Zhaia, Y.; Baran, P.K. Do configurational attributes matter in context of urban parks? Park pathway configurational attributes and senior walking. Landsc. Urban Plan. 2016, 148, 188-202. [CrossRef]

4. Cho, M.-R. The politics of urban nature restoration: The case of Cheonggyecheon restoration in Seoul, Korea. Int. Dev. Plan. Rev. 2010, 32, 145-165. [CrossRef]

5. Kim, D. Urban Form Study of Seoul; Seoul Development Institute: Seoul, Korea, 2010.

6. Shin, H. Property-based redevelopment and gentrification: The case of Seoul, South Korea. Geoforum 2009, 40, 906-917. [CrossRef]

7. Statistics Korea. Available online: http://kostat.go.kr/portal/korea/index.action (accessed on 1 September 2016).

8. Kim, H.-S. Disputes on the Capital transfer in the early stage of the Joseon Dynasty. J. Korea Plan. Assoc. 2009, $44,21-36$.

9. Kim, H.M.; Han, S.S. Seoul. Cities 2012, 29, 142-154. [CrossRef]

10. Kwon, Y.-S.; Jeon, B.; Kim, S. The seventeenth-century transition of Seoul's spatial structure to functional pragmatism. J. Asian Archit. Build. Eng. 2015, 14, 419-426. [CrossRef]

11. Jang, M.; Kang, C.D. Urban greenway and compact land use development: A multilevel assessment in Seoul, South Korea. Landsc. Urban Plan. 2015, 143, 160-172. [CrossRef]

12. Kostopoulou, S. On the revitalized waterfront: Creative milieu for creative tourism. Sustainability 2013, 5, 4578-4593. [CrossRef]

13. Schuetze, T.; Chelleri, L. Urban sustainability versus green-washing-Fallacy and reality of urban regeneration in downtown Seoul. Sustainability 2016, 8, 33. [CrossRef]

14. Lee, M.-B. Cheonggyecheon Flows to the Future; Seoul Random House JoongAng: Seoul, Korea, 2007; pp. 174-179.

15. Jumg-Gu Office. Available online: http://www.junggu.seoul.kr/index.jsp (accessed on 1 September 2016).

16. Seoul Metropolitan Facilities Management Corporation. Available online: http://www.cheonggyecheon.or.kr (accessed on 1 September 2016).

17. KBS News. U.S. Army corps and National medical Center. Available online: http://news.kbs.co.kr/news / view.do?ncd=2974209 (accessed on 1 September 2016).

18. Kim, B. Urban typological analysis of the Cheonggye Stream Restoration Project in Seoul. Korea Spat. Plan. Rev. 2007, 53, 111-130.

19. Park, K.-D. Cheonggyecheon Restoration Project. In Proceedings of the JFES-WFEO Joint International Symposium on River Restoration, Japan Federation of Engineering Societies and the World Federation of Engineering Organizations, Hiroshima, Japan, 13 September 2007.

20. Kim, S.-H.; Jung, S.-H.; Rowe, P.G. A City and Its Stream: An Appraisal of the Cheonggyecheon Restoration Project and Its Environs in Seoul, South Korea; Harvard Universtiy: Boston, MA, USA, 2010.

21. Seoul Metropolitan Government. White Paper on the Cheonggyecheon Restoration Project; Seoul Metropolitan Government: Seoul, Korea, 2006; pp. 85-86.

22. Discovery Channel. Man-Made Marvels, Seoul Searching. 2005. Available online: http://881144g.com/ 53684-man-made-marvels-seoul-searching-2005.html (accessed on 1 January 2016).

23. Seoul Development Institute. Seoul CBD Development Plans Regarding Cheonggyecheon Restoration Project; Seoul Development Institute: Seoul, Korea, 2004.

24. Photos. Available online: http:/ / egloos.com (accessed on 1 October 2015).

25. Korea Ministry of Government Legislation. Available online: http://www.law.go.kr/main.html (accessed on 1 September 2016). 
26. Newsis. Cheonggyecheon Stream. Available online: http://www.newsis.com/ar_detail/view.html?ar_id= NISX20141126_0013320888 (accessed on 1 September 2016).

27. Hwang, J.-Y.; Cho, G.-C.; Yang, S.-W. Analysis on the behavioral characteristics of visitors to Cheonggyecheon in Seoul. J. Archit. Inst. Korea 2011, 27, 185-192.

28. Sohn, S.J. A study on the revitalization of culture-tourist place through the actual condition and the using of Cheonggyecheon urban-waterfront. Korea Cult. Tour. Inst. 2008, 10, 59-70.

29. Jo, M.-H.; Jo, Y.W.; Kim, S.J. The application of ASTER TIR satellite imagery data for surface temperature change analysis-A case study of Cheonggye Stream Restoration Project. Korean Assoc. Geogr. Inf. Stud. 2009, $12,73-80$.

30. Kim, K.T.; Song, J. The effect of the Cheonggyecheon Restoration Project on the Mitigation of Urban Heat Island. J. Korea Plan. Assoc. 2015, 50, 139-154. [CrossRef]

31. Conzen, M.P.; Gu, K.; Whitehand, J.W.R. Comparing traditional urban form in China and Europe: A fringe-belt approach. Urban Geogr. 2012, 33, 22-45. [CrossRef]

32. National Spatial Information Clearinghouse. Available online: http://www.nsic.go.kr/ndsi/main.do (accessed on 1 January 2016).

33. Electronic Architectural administration Information System. Available online: http://www.eais.go.kr/ (accessed on 1 January 2016).

34. Oliveira, V. Morpho: A methodology for assessing urban form. Urban Morphol. 2013, 17, 21-33.

35. Hillier, B. Spatial sustainability in cities: Organic patterns and sustainable forms. In Proceedings of the 7th International Space Syntax Symposium, Royal Institute of Technology, Stockholm, Sweden, 8-11 June 2009.

36. Turner, A. From axial to road-centre lines: A new representation for space syntax and a new model of route choice for transport network analysis. Environ. Plan. B Plan. Des. 2007, 34, 539-555. [CrossRef]

37. Daum Map. Available online: http://map.daum.net/ (accessed on 9 November 2016).

38. Song, H.-S.; Oh, H.-K.; Kim, J.-H.; Kim, K-H. A study on the characteristics and change of urban form is Gwancheol-dong. In Proceedings of the Conference of the Urban Design Institute of Korea, Gwangju, Korea, 11 Novermber 2006.

39. Chae, H.; Kim, T.-H.; Choi, Y.-R. A study on the correlation of changing pedestrian network and building uses due to the restoration project of Cheonggyecheon. Seoul Stud. 2009, 10, 169-182.

40. Dooho, L.; Changmo, A. Architectural Reinterpretation of Sewoon Sanga. In Proceedings of the Conference of Korean Association of Architectural History, Gwangju, Korea, 2011.

41. Kang, M.-S. A Redevelopment Proposal for Revitalizing Specialized Printing Market Area (Bang-San Market) in Seoul. Master's Thesis, Hanyang University, Seoul, Korea, 2003.

42. Sewoon Sanga Redevelopment. Naver News, 13 July 2008. Available online: http:/ / news.naver.com/main/ read.nhn?mode=LSD\&mid=sec\&sid1=101\&oid=277\&aid=0002002402 (accessed on 8 November 2015).

43. Yoon, S.J. Sewoon Sanga apartment. Rev. Archit. Build. Sci. 1994, 15, 14-16.

44. Kim, J.I. A study on the reformation of the traditional clothing markets in Seoul. J. Korea Plan. Assoc. 2001, 36, 235-256.

45. Kwon, H.-J.; Kim, S.-Y.; Won, H.-Y. A study on the factors determining visits of Dongdeamoon Shopping Mall: Focusing on Dosan Tower and Good-Morning City Shopping Mall. Korean J. Hotel Adm. 2011, 20, 209-223.

46. Pyounghwa Market. Available online: http://www.pyounghwa.com/company/com_2.php (accessed on 1 September 2016).

47. TBS. Available online: http://tbs.seoul.kr/tv/Seoul_time/index.jsp (accessed on 10 October 2015).

48. Kim, J.I.; Lee, C.M.; Ahn, K.H. Dongdaemun, a traditional market place wearing a modern suit: The importance of the social fabric in physical redevelopments. Habitat Int. 2004, 28, 143-161. [CrossRef]

49. Park, H.-R.; Park, M.-R. The present state of E-business according to the establishment year and the sales approach of Dongdaemun Clothing Market. Fash. Bus. 2002, 6, 125-135.

50. Yun, J. Construction of the world design capital: Detournement of spectacle in Dongdaemun Design Park \& Plaza in Seoul. J. Asian Archit. Build. Eng. 2014, 24, 17-24.

51. Dongdaemun Shopping Complex. Available online: http://www.ddm-mall.com (accessed on 1 September 2016).

52. DDP. Available online: http://www.ddp.or.kr (accessed on 1 September 2016).

53. Doopedia. Available online: http://www.doopedia.co.kr/search/encyber/new_totalSearch.jsp (accessed on 1 September 2016). 
54. Gwak, M.; Lee, S.-G.; Lee, W. The Economics of the Dongdaemun Success; Issue Today: Seoul, Korea, 2002.

55. Seoul Metropolitan Facilities Management Corporation. Available online: http://www.sisul.or.kr/open_ content/cheonggye/ (accessed on 1 January 2016).

56. Scott, A.J.; Storper, M. Regions, globalization, development. Reg. Stud. 2003, 37, 579-593. [CrossRef]

(C) 2016 by the authors; licensee MDPI, Basel, Switzerland. This article is an open access article distributed under the terms and conditions of the Creative Commons Attribution (CC-BY) license (http:/ / creativecommons.org/licenses/by/4.0/). 